\title{
Recurrent Guillain-Barré Syndrome with Anti-GT1a and Anti-GQ1b Ganglioside Antibodies
}

\author{
Jihyeon Hwang ${ }^{a}$ \\ Ye-Ji Kwon ${ }^{a}$ \\ Jong Kuk Kim ${ }^{\text {b,c }}$ \\ Nam Jun Kim ${ }^{\mathrm{C}}$ \\ Seol-Hee Baek \\ aDepartment of Neurology, \\ Korea University Anam Hospital, \\ Korea University College of Medicine, \\ Seoul, Korea \\ ${ }^{b}$ Department of Neurology, \\ Dong-A University College of Medicine \\ Busan, Korea \\ 'Peripheral Neuropathy Research Center, \\ Dong-A University College of Medicine, \\ Busan, Korea
}

Dear Editor,

Recurrent Guillain-Barré syndrome (GBS) is a rare condition that reportedly appears in $2-5 \%$ of patients with GBS. ${ }^{1}$ The clinical and pathophysiological characteristics of recurrent GBS have not been fully elucidated. Anti-ganglioside antibodies have been reported in a small number of cases of recurrent GBS. Herein we report on a case of recurrent GBS with anti-GT1a and anti-GQ1b ganglioside antibodies.

A previously healthy 63-year-old man arrived at the emergency room with a 1-day history of dysarthria and right facial sensory change. Additional symptoms of facial diplegia, external ophthalmoplegia, truncal ataxia, and areflexia developed on the third day of admission. The findings of a nerve conduction study (NCS) and CSF analysis were unremarkable. Antiganglioside study was performed using the enzyme-linked immunosorbent assay for antiganglioside antibodies as described previously, ${ }^{2}$ and revealed positivity for anti-GT1a (3+) and anti-GQ1b (1+) IgG antibodies. Intravenous immunoglobulin (IVIG) was administered at $0.4 \mathrm{~g} / \mathrm{kg} /$ day for 5 days from the sixth day after onset. The symptoms of the patient improved gradually after IVIG termination. At 10 days after the 5-day course of IVIG, his neurological deficits had fully recovered except for the ophthalmoplegia. The remaining ophthalmoplegia improved following bilateral medial rectus muscle resection at 6 months after symptom onset. The patient could perform all of the normal activities of daily living, including driving, after the procedure.

The patient was readmitted 12 months after the first attack complaining of paresthesia in both legs. An upper respiratory infection had appeared 1 week previously. These symptoms progressed from both lower extremities to both upper extremities and his face. A neurological examination revealed truncal ataxia and hyporeflexia in both upper and lower extremities along with paresthesia. A CSF analysis produced unremarkable findings, while a motor NCS revealed prolonged distal motor latency with conduction blocks in the bilateral median and ulnar nerves. A sensory NCS revealed the absence of distal sensory nerve action potentials in the median, ulnar, peroneal, and sural nerves. The anti-ganglioside antibody assay was positive for anti-GT1a (1-2+) and anti-GQ1b (1-2+) IgG antibodies, which were the same antibodies present during the previous attack. A laboratory test indicated that the vitamin levels and thyroid function were within the normal limits. Brain MRI findings were unremarkable. Following a diagnosis of GBS, IVIG was administered at $0.4 \mathrm{~g} / \mathrm{kg} /$ day for 5 days from the day after symptom onset, but his symptoms worsened. Ophthalmoplegia and quadriplegia developed on the fifth day from symptom onset. His symptoms appeared to gradually improve after IVIG termination, but they worsened again 2 weeks later. A second cycle of IVIG at $0.4 \mathrm{~g} / \mathrm{kg} /$ day for 5 days was administered from day 20 after symptom onset. The patient had recovered fully at 1 month after the second cycle of IVIG treatment.

This patient had experienced two independent episodes of GBS involving the presence of

@ This is an Open Access article distributed under the terms of the Creative Commons Attribution Non-Commercial License (https://creativecommons.org/licenses/by-nc/4.0) which permits unrestricted non-commercial use, distribution, and reproduction in any medium, provided the original work is properly cited. 
Table 1. Anti-ganglioside antibodies in recurrent Guillain-Barré syndrome

\begin{tabular}{|c|c|c|c|c|c|c|c|c|}
\hline No. & Sex & $\begin{array}{l}\text { Age, } \\
\text { years }\end{array}$ & Episode & $\begin{array}{l}\text { Preceding } \\
\text { infection }\end{array}$ & Clinical manifestations & NCS findings & Ganglioside Abs & Reference \\
\hline \multirow[t]{2}{*}{1} & $\mathrm{~F}$ & 38 & First & Gastroenteritis & $\begin{array}{l}\text { Quadriparesis (ascending pattern) } \\
\text { and facial diplegia }\end{array}$ & Motor neuropathy with $\mathrm{CB}$ & NA & 5 \\
\hline & & 39 & Second & URI & $\begin{array}{l}\text { Quadriparesis (descending pattern) } \\
\text { and bulbar symptoms }\end{array}$ & Motor neuropathy with CB & $\lg \mathrm{G}$ anti-GD1a & \\
\hline \multirow[t]{3}{*}{2} & M & 58 & First & None & $\begin{array}{l}\text { Cerebellar ataxia, ptosis, and } \\
\text { paresthesia }\end{array}$ & $\begin{array}{l}\text { Sensory neuropathy, } \\
\text { unclassified }\end{array}$ & NA & 3 \\
\hline & & 65 & Second & URI & $\begin{array}{l}\text { Cerebellar ataxia, ptosis, and } \\
\text { paresthesia }\end{array}$ & $\begin{array}{l}\text { Sensory neuropathy, } \\
\text { unclassified }\end{array}$ & $\begin{array}{l}\lg G \text { anti-GD1b } \\
\text { and anti-G01b }\end{array}$ & \\
\hline & & 68 & Third & Arthralgia & $\begin{array}{l}\text { Cerebellar ataxia, ptosis, and } \\
\text { paresthesia }\end{array}$ & $\begin{array}{l}\text { Sensory neuropathy, } \\
\text { unclassified }\end{array}$ & $\begin{array}{l}\lg G \text { anti-GD1b } \\
\text { and anti-G01b }\end{array}$ & \\
\hline \multirow[t]{2}{*}{3} & M & 29 & First & None & Quadriparesis & $\begin{array}{l}\text { Motor neuropathy with } \mathrm{CB} \text {, } \\
\text { demyelinating }\end{array}$ & NA & 3 \\
\hline & & 40 & Second & Gastroenteritis & Quadriparesis & $\begin{array}{l}\text { Motor neuropathy with } \mathrm{CB}_{\text {, }} \\
\text { demyelinating }\end{array}$ & $\begin{array}{l}\operatorname{Ig} \mathrm{G} \text { anti-GD1b } \\
\text { and anti-GM1 }\end{array}$ & \\
\hline \multirow[t]{3}{*}{4} & $\mathrm{~F}$ & 56 & First & None & Distal leg weakness and sensory loss & $\begin{array}{l}\text { SM polyneuropathy with } \mathrm{CB}_{\text {, }} \\
\text { demyelinating }\end{array}$ & NA & 3 \\
\hline & & 68 & Second & URI & Distal leg weakness and sensory loss & $\begin{array}{l}\text { SM polyneuropathy with } \mathrm{CB}_{\text {, }} \\
\text { demyelinating }\end{array}$ & NA & \\
\hline & & 69 & Third & Gastroenteritis & Distal leg weakness and sensory loss & $\begin{array}{l}\text { SM polyneuropathy, } \\
\text { demyelinating }\end{array}$ & $\operatorname{lgM}$ anti-GM1 & \\
\hline \multirow[t]{3}{*}{5} & M & 25 & First & URI & $\begin{array}{l}\text { Bulbar symptoms, ophthalmoplegia, } \\
\text { ataxia, and quadriparesis }\end{array}$ & $\begin{array}{l}\text { SM polyneuropathy, } \\
\text { unclassified }\end{array}$ & $\begin{array}{l}\lg G \mathrm{GA} 1 \text { and } \\
\text { GSC-Abs }\end{array}$ & 4 \\
\hline & & 28 & Second & URI & $\begin{array}{l}\text { Bulbar symptoms, ophthalmoplegia, } \\
\text { ataxia, and weakness of the lower } \\
\text { extremities }\end{array}$ & $\begin{array}{l}\text { SM polyneuropathy, } \\
\text { unclassified }\end{array}$ & GSC-Abs & \\
\hline & & 33 & Third & URI & $\begin{array}{l}\text { Bulbar symptoms, ophthalmoplegia, } \\
\text { quadriparesis, tremor, and disturbed } \\
\text { consciousness }\end{array}$ & $\begin{array}{l}\text { SM polyneuropathy, } \\
\text { demyelinating }\end{array}$ & GSC-Abs & \\
\hline \multirow[t]{2}{*}{6} & M & 63 & First & None & $\begin{array}{l}\text { Bulbar symptoms, ophthalmoplegia, } \\
\text { and ataxia }\end{array}$ & Unremarkable & $\begin{array}{l}\lg \mathrm{G} \text { anti-GT1a and } \\
\text { anti-G01b }\end{array}$ & Our case \\
\hline & & 64 & Second & URI & $\begin{array}{l}\text { Bulbar symptom, ophthalmoplegia, } \\
\text { ataxia, and quadriparesis }\end{array}$ & $\begin{array}{l}\text { SM polyneuropathy with } \mathrm{CB}_{\text {, }} \\
\text { demyelinating }\end{array}$ & $\begin{array}{l}\lg \mathrm{G} \text { anti-GT1a and } \\
\text { anti-G01b }\end{array}$ & \\
\hline
\end{tabular}

CB: conduction block, F: female, GSC-Abs: anti-ganglioside complex antibodies, M: male, NA: not applicable, NCS: nerve conduction study, SM: sensorimotor, URI: upper respiratory tract infection.

the same anti-ganglioside antibodies during each attack. A few cases of recurrent GBS with anti-ganglioside antibodies have been reported, and are summarized in Table $1 .^{3-5}$ Previous reports of recurrent GBS with anti-ganglioside antibodies have described shorter intervals between the attacks and more-severe neurological deterioration during recurrences. Recurrent GBS is typically reported to present with similar clinical manifestations during different attacks even when different conditions are present prior to the attacks. ${ }^{3}$ However, some cases of recurrent GBS with different phenotypes during recurrent attacks have been reported. ${ }^{4}$ These findings suggest that genetic or immunological factors are associated with the pathogenesis of recurrent GBS.

In conclusion, the clinical manifestations of recurrent GBS are heterogeneous, and the associated risk factors remain unclear. Genetic and immunological host factors and anti-ganglioside antibodies might affect the clinical manifestations and pathophysiology of recurrent GBS. Further studies are needed to obtain a deeper understanding of the clinical and pathophysiological factors underlying recurrent GBS.

\section{Conflicts of Interest}

The authors have no potential conflicts of interest to disclose. 


\section{Acknowledgements}

This study was supported by the National Research Foundation of Korea (NRF) grant funded by the Korea government (MEST) (No. 2016R1A5A 2007009).

\section{REFERENCES}

1. Grand'Maison F, Feasby TE, Hahn AF, Koopman WJ. Recurrent Guillain-Barré syndrome. Clinical and laboratory features. Brain 1992;115: 1093-1106.

2. Kim JK, Bae JS, Kim DS, Kusunoki S, Kim JE, Kim JS, et al. Prevalence of anti-ganglioside antibodies and their clinical correlates with
Guillain-Barré syndrome in Korea: a nationwide multicenter study. J Clin Neurol 2014;10:94-100.

3. Pyun SY, Jeong JH, Bae JS. Recurrent Guillain-Barré syndrome presenting stereotypic manifestations, positive antiganglioside antibodies, and rapid recovery. Clin Neurol Neurosurg 2015;139:230-233.

4. Ito H, Hatanaka Y, Fukami Y, Harada Y, Kobayashi R, Okada H, et al. Anti-ganglioside complex antibody profiles in a recurrent complicated case of GQ1b-seronegative Miller Fisher syndrome and Bickerstaff brainstem encephalitis: a case report. BMC Neurol 2018;18:72.

5. Yalinay Dikmen P, Emre Oge A. Recurrent GBS with GDla anti-ganglioside antibodies. J Peripher Nerv Syst 2012;17:135-137. 